\title{
Bolstering Immunity through Pattern Recognition Receptors: A Unique Approach to Control Tuberculosis
}

\author{
Susanta Pahari, Gurpreet Kaur, Mohammad Aqdas, Shikha Negi, Deepyan Chatterjee, \\ Hilal Bashir, Sanpreet Singh and Javed N. Agrewala* \\ Immunology Laboratory, CSIR-Institute of Microbial Technology, Chandigarh, India
}

The global control of tuberculosis (TB) presents a continuous health challenge to mankind. Despite having effective drugs, TB still has a devastating impact on human health. Contributing reasons include the emergence of drug-resistant strains of Mycobacterium tuberculosis (Mtb), the AIDS-pandemic, and the absence of effective vaccines against the disease. Indeed, alternative and effective methods of TB treatment and control are urgently needed. One such approach may be to more effectively

OPEN ACCESS

Edited by:

Robert Braidwood Sim,

University of Leicester,

United Kingdom

Reviewed by:

Anthony George Tsolaki,

Brunel University London,

United Kingdom

Taruna Madan,

National Institute for Research in

Reproductive Health, India

*Correspondence:

Javed N. Agrewala

javed@imtech.res.in

Specialty section:

This article was submitted to

Molecular Innate Immunity,

a section of the journal

Frontiers in Immunology

Received: 16 March 2017

Accepted: 14 July 2017

Published: 02 August 2017

Citation:

Pahari S, Kaur G, Aqdas M, Negi S, Chatterjee $D$, Bashir $H$, Singh $S$ and Agrewala JN (2017) Bolstering

Immunity through Pattern

Recognition Receptors: A Unique

Approach to Control Tuberculosis.

Front. Immunol. 8:906.

doi: 10.3389/fimmu.2017.00906 engage the immune system; particularly the frontline pattern recognition receptor (PRR) systems of the host, which sense pathogen-associated molecular patterns (PAMPs) of Mtb. It is well known that $95 \%$ of individuals infected with Mtb in latent form remain healthy throughout their life. Therefore, we propose that clues can be found to control the remainder by successfully manipulating the innate immune mechanisms, particularly of nasal and mucosal cavities. This article highlights the importance of signaling through PRRs in restricting Mtb entry and subsequently preventing its infection. Furthermore, we discuss whether this unique therapy employing PRRs in combination with drugs can help in reducing the dose and duration of current TB regimen.

Keywords: tuberculosis, immunomodulation, innate cells, innate molecules, pattern recognition receptors

\section{INTRODUCTION}

Mycobacterium tuberculosis (Mtb) is the causative agent of tuberculosis (TB). It remains a major health problem worldwide. It is responsible for over 10.4 million cases and 1.8 million deaths annually (1). About one-third of the global population is infected with $M t b$ but only $5-10 \%$ succumb to disease $(2,3)$. The failure of BCG vaccine to protect against TB, AIDS-pandemic, and the emergence of drug resistance of $M t b$ has further exacerbated the problem (4). The current lengthy regimen for TB treatment is full of complexity and inflicts patients with severe side-effects $(5,6)$. Hence, it is imperative to design novel and unique strategies that can overcome the problems associated with current treatment.

Host immunity successfully imparts optimum protection against the majority of pathogens (7-11). However, the success of $M t b$ to establish pathogenicity is due to its unique ability to skillfully tame and tune host immune responses and reside in the hostile environment, waiting for the right moment to take over the host immunity (11). Although our immune system sufficiently protects 90-95\% of latently infected individuals from developing the disease, the remaining 5-10\% of individuals are unable to restrict the growth of $M t b$. T cells of adaptive immunity are known to play an important role in controlling the survival of the bacterium during latency, as well as in disease progression (12). Importantly, the role of innate immunity is considered more crucial than adaptive 
immunity since it acts as the first line of defense in combating the pathogen during the early phase of infection; much before adaptive immunity comes into operation. Adaptive immunity retains very high antigenic specificity through $\mathrm{T}$ cell receptors and $B$ cell receptors. By contrast, innate immunity maintains specificity through pattern recognition receptors (PRRs) by recognizing conserved molecular structures that are expressed by a large variety of microbes known as "pathogen-associated molecular patterns" (PAMPs) (13). PRRs, such as toll-like receptors (TLRs), C-type lectin receptors (CLRs), NOD-like receptors (NLRs), dendritic cell (DC)-specific intercellular adhesion molecule-3-grabbing non-integrin (DC-SIGN), and mannose receptor are constitutively expressed on an array of cells that are devoted to perform functions not only for innate immunity but for adaptive immunity as well (14). Recently, the role of TLRs, CLRs, NLRs, and DC-SIGN have gained considerable attention following the observations that these molecules play a cardinal role not only in assisting the cells in capturing and internalization of the microbes but also in delivering the sequence of signaling events necessary for stimulating immunity and eliminating pathogens. Many PRR agonists are available commercially to study PRR-mediated activation of the immune response (15-18). Consequently, it may be quite important to utilize the agonists of PRRs as immunotherapeutic agents to control and eradicate $M t b$ infection and to minimize the chance of developing drug resistance.

\section{ROLE OF INNATE IMMUNE CELLS IN CONTROLLING THE PROPAGATION OF Mtb}

Our immune system is made up of a powerful combination of cells of innate and adaptive arms of immunity. In spite of the fact that innate immunity is the first line of defense against numerous invading pathogens, its importance has long been ignored due to the belief of its non-specific nature and inability to generate longterm protection (19). However, several studies have emerged during the last decades that could overcome this belief and establish the real importance of innate immunity. Innate immunity not only discriminates between the varieties of pathogens, including $M t b$, but also contributes to sustained immunity (20-22). The importance of the cells of innate immunity can be accounted in individuals who are tuberculin-negative due to the absence of $\mathrm{T}$ cell immunity but are still protected against $M t b(23,24)$. The sentinels of innate immunity include monocytes, macrophages, DCs, neutrophils, and natural killer (NK) cells. These cells contribute prominently in the eradication of $M t b$ by employing a variety of PRRs to recognize mycobacterium-specific PAMPs, such as carbohydrate and lipid moieties. Many PRRs directly elicit phagocytosis of $M t b$ and thereby stimulate secretion of cytokines, chemokines, and activation of the cascade of complement components. Complement components play a pivotal role in promoting the opsonization of pathogens.

Mycobacterium tuberculosis has a potential to virtually infiltrate every organ of the body, but lungs are the most preferred site for infection. The bacterium enters the nasal cavity and reaches lung via the respiratory tract. In the respiratory tract, neutrophils are the first cells to encounter $M t b$. Neutrophils residing in our mucosa responds via neutrophil extracellular traps. After phagocytosing the $M t b$, neutrophils alert the other cells of the immune system by releasing pro-inflammatory cytokines, free radicals, and chemokines (25). As a result, other components of respiratory mucosa, such as epithelial cells, connective tissues, macrophages, and DCs, get activated. Epithelial cells of mucosal lining have a potential to recognize the PAMPs of $M t b$ through their PRRs and subsequently, produce interferon (IFN)- $\gamma$, tumor necrosis factor (TNF)- $\alpha$, and granzymes; which are the key contributors in the elimination of $M t b$ (26). Mucosal DCs present in the lung parenchyma and alveolar tracts are pivotal responders against $M t b(27)$. NK cells are the direct killers of infected macrophages and producers of major cytokines, such as type I IFNs and IFN- $\gamma$, which are essential for the activation of DCs and macrophages. Furthermore, even $\gamma \delta$ T cells contribute in initiating the defense mechanism against $M t b$. Moreover, $\gamma \delta$ $\mathrm{T}$ cells act as antigen-presenting cells (APCs) to activate CD4 $\mathrm{T}$ cells, cross-present antigen to CD8 T cells, and produce IL-17 and IFN- $\gamma$ in the lungs (28).

Mycobacterium tuberculosis can only reach the lungs upon successfully evading the innate immune response of the nose and upper respiratory tract. Henceforth, the nasal immunity is a strong checkpoint in controlling TB. The alveolar macrophages, which are highly professional phagocytic cells of innate immunity, are activated to engulf and destroy $M t b$. In addition, DCs, neutrophils, and NK cells coordinate with each other in eliminating the bacteria. Correspondingly, APCs, such as DCs and macrophages, contribute in bridging the innate and adaptive immunity $(20,29)$. Macrophages and DCs possess PRRs that can sense PAMPs and their agonists, such as lipoarabinomannan, zymosan, CpG ODNs DNA, LPS, trehalose-6,6 dimycolate (TDM), TDB, curdlan, triacylated lipopeptide, MDP (muramyl dipeptide), and N-glycolyl MDP. Sensing of PAMPs by PRRs can induce and enhance the expression of MHC, co-stimulatory molecules, and adhesion molecules, as well as cause the release of many soluble mediators, such as cytokines, chemokines, and free radicals. In addition, PRRs induce the production of reactive oxygen intermediates, reactive nitrogen intermediates, and enhance apoptosis, autophagy, and inflammasome formation (30-35). Thus, optimal activation of various bactericidal mechanisms through immunomodulators can be an excellent approach to treat TB.

\section{NASAL AND ORAL IMMUNE DEFENSE: FRONTLINE BARRIERS TO FORBID THE ENTRY OF Mtb}

The nasal cavity is the major site through which $M t b$ enters the lungs and establish infection. Therefore, strengthening nasal immunity is of pivotal importance. Thus, physical barriers of the nose and mucosal epithelium are important components of the nasal innate immunity that provide defense against $M t b$. In this context, mucin produced by mucosal epithelium prevents the entry and attachment of the invading pathogen. Furthermore, the mucosa-associated lymphoid tissue employs 
various checkpoints against $M t b$. Also, nasal immunity is highly enriched with phagocytic cells that are sufficiently endowed with the capability to prevent the entry as well as promote killing of $M t b$ by producing antimicrobial peptides, nitric oxide, lysozyme, defensins, mucins, cytokines, and chemokines (36). These phagocytic cells not only kill the pathogen at an early stage of infection but also process and present antigens to activate the cells of adaptive immunity (36). IgA produced by B cells contributes sufficiently against $M t b(37,38)$. Hence, the cells of the innate immunity of nose coordinate with the adaptive immunity to control infections. Considering the extremely important role of nasal immunity, vaccines against polio, typhoid, cholera, rotavirus, and small pox have been exceptionally successful in eliminating these diseases by bolstering nasal immunity (39).

Another important compartment of the body that works as a checkpoint to control the infection is the oral cavity. It encompasses a well-compartmentalized network of cells that imparts a protective immunity and shields from invading pathogens (40). Recently, the role of commensals has been linked to elegantly contribute in boosting oral immunity (41-45). This highlights the importance of the cells of the oral cavity and commensals to subvert infection and protect against the pathogens. Importantly, bolstering the oral immunity through immunomodulators can be quite crucial in restricting $M t b$ pathogenicity. Potential targets for such therapy include the epithelial cells and resident mucosal DCs that have array of PRRs to trigger their activation (46). Since $M t b$ exploits both nasal and oral routes to enter the body and establish infection, there is a strong incentive to develop a successful vaccine against TB by adjuvanting resident immune cells of the nasal and oral cavity by targeting PRRs, thereby optimally boosting the immunity and, consequently eliminating invading mycobacterium at the entry point (Figure 1).

\section{IMPORTANCE OF LUNG IMMUNITY IN PREVENTING Mtb INFECTION}

If $M t b$ evades nasal immunity and reaches lungs, both local immunity in the lungs and systemic immune responses are involved in combating the pathogen. Recently, many studies

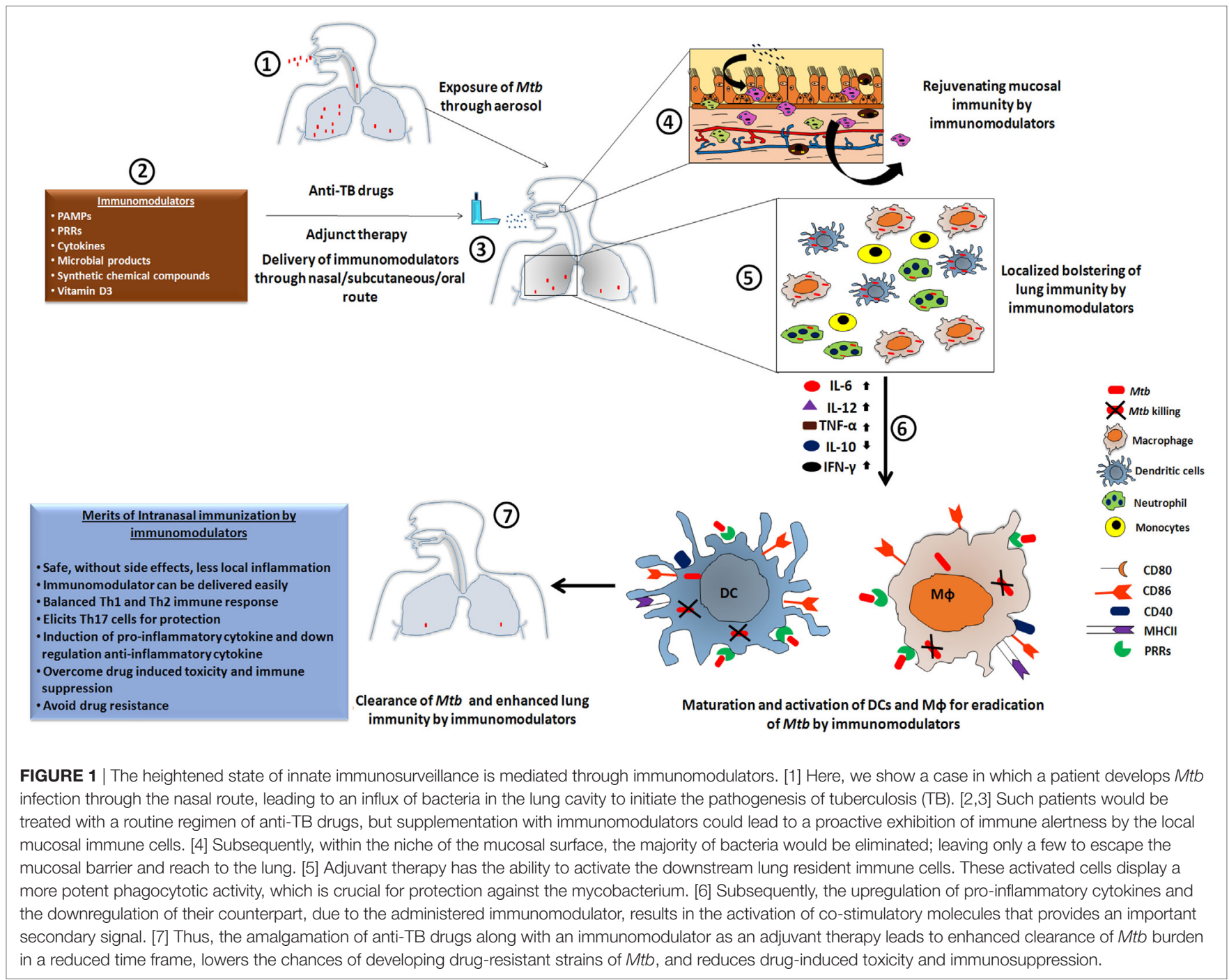


suggest a decisive role of immunomodulators in controlling infections and metabolic disorders (47-50). Unfortunately, not much has been explored in the case of TB. The lung is a highly vascularized organ and enriched with the cells of innate and adaptive immunity. Like nasal immunity, the cells of the innate immunity in lungs, such as alveolar macrophages, DCs, neutrophils, and NK cells, play a fundamental role in early detection of $M t b$ through PRRs and thereby alerting the cells of the immune system. Accordingly, the cells secrete an array of soluble mediators, such as free radicals, cytokines, chemokines, and elicit autophagy, apoptosis, and inflammasome formation to eradicate $M t b$ before it can effectively establish infection in the lung. Pulmonary collectins, hydrophilic surfactant proteins A and D (SP-A and SP-D) are known to regulate pulmonary host defense and inflammation. SP-A and SP-D are produced predominantly by type II alveolar cells. It has been reported that SP-A and SP-D play pivotal role in promoting lung innate immunity (51). SP-A and SP-D are known to directly interact with macrophages and enhance their phagocytic potential against pathogens, such as Streptococcus pneumoniae and $M t b$ by upregulating the cell surface localization of phagocytic receptors (52). Interestingly, majority of tuberculin-negative individuals remain protected throughout their lifetime against $M t b(1,23,24)$. Thus, signifying that not only adaptive immunity plays the crucial role but innate immunity can efficiently contribute in controlling the disease (Figure 2).

Therefore, it may be crucial to consider both adaptive and innate immunity in enhancing the nasal immune responses to

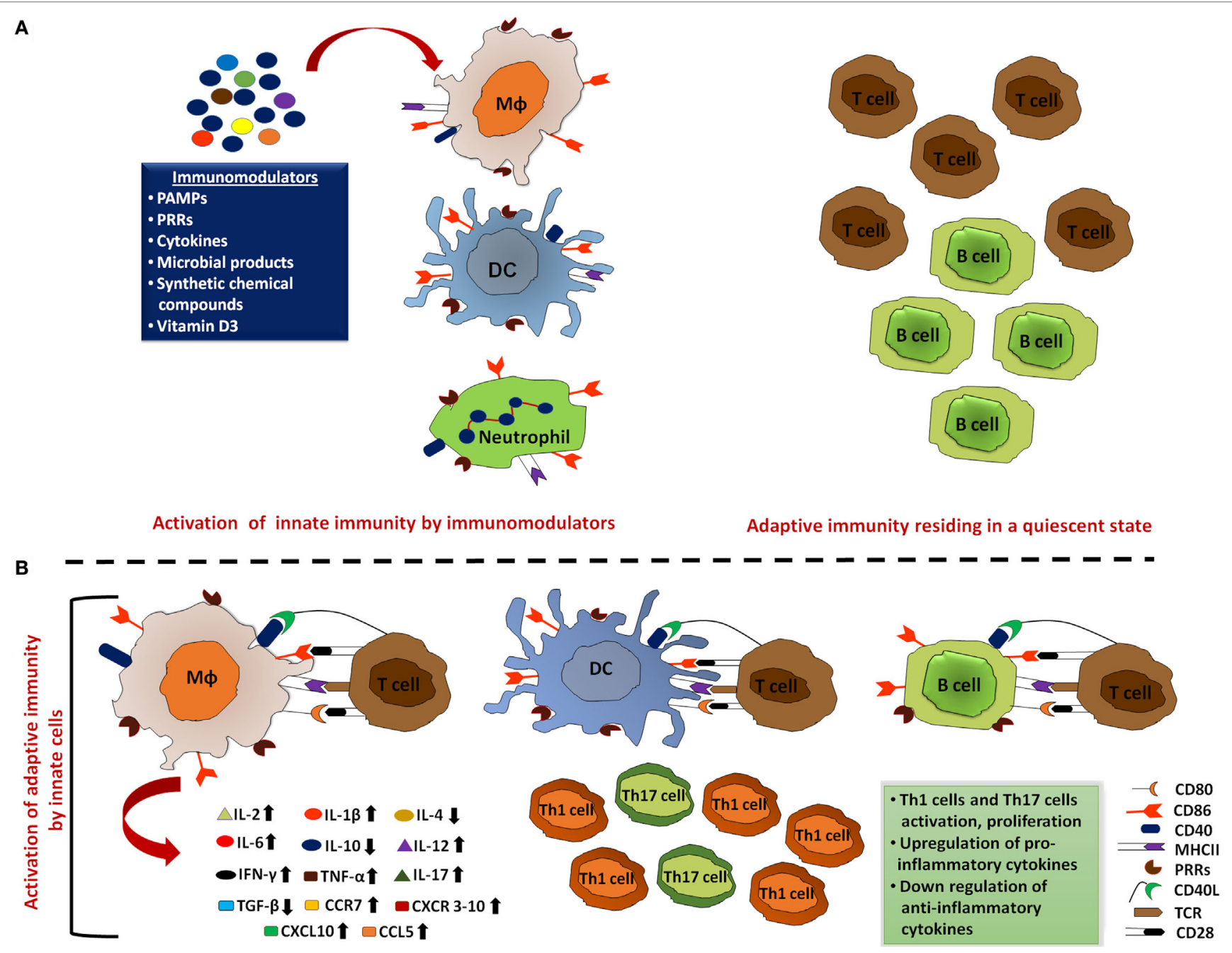

FIGURE 2 | Activated innate immunity by immunomodulators meticulously clears the pathogens. (A) Innate cells that include macrophages, dendritic cells (DCs), and neutrophils act as the first line of defense to mount an immune response against the invading pathogens. Thus, aptly arming these cells by employing immunomodulators can ensure rapid activation of the innate cells and promote clearance of the majority of microbes during the initial encounter. In addition, immunomodulator-mediated upregulation of $\mathrm{MHC}$, co-stimulatory molecules, and cytokines enhance the processing and presentation capability of these professional antigen-presenting cells (APCs). Such activation of innate cells effectively clears most of the pathogens without activating adaptive immune responses. (B) These immunologically activated innate cells also alert adaptive immune cells to ensure the elimination of remaining pathogens that escaped APC clearance. These activated $\mathrm{T}$ cells and B cells further induce pro-inflammatory cytokine production, inhibit the production of anti-inflammatory cytokines, and inhibit the activation and proliferation of Th1 and Th17 cells. 
prevent $M t b$ reaching the lung. In connection with this, understanding the sequence of signaling events operating through PRRs to optimally activate immunity against $M t b$ can be decisive in developing or designing adjuvants that can substantially supplement vaccines and immunotherapies.

\section{TARGETING PRR-ASSOCIATED MOLECULES TO REGULATE INNATE IMMUNITY}

\section{Toll-Like Receptors}

Toll-like receptors are the most extensively studied class of PRRs. They are one of the components of the immune system to first encounter pathogens. Structurally, TLRs are type I transmembrane proteins that are composed of an ectodomain, a transmembrane region, and cytosolic Toll-IL-1 receptor (TIR) domain that trigger downstream signaling pathways. TLRs recognize a wide array of extracellular or intracellular PAMPs (53). So far, around 10-12 functional TLRs have been identified in both mice and humans. Each TLR detects discrete PAMPs derived from distinct classes of pathogens, including bacteria, viruses, fungi, and parasites. These include lipoproteins (TLR-1, TLR-2, and TLR-6); double-stranded (ds) RNA (TLR-3); LPS (TLR-4); flagellin (TLR-5); single-stranded (ss) RNA (TLR-7 and TLR-8); and CpG ODNs DNA (TLR-9) (53). Upon PAMP recognition, TLRs recruit a specific set of adaptor molecules, which bind to TIR domains, such as MyD88 (myeloid differentiation primary response gene 88 ) and TRIF (TIR-domain-containing adapter-inducing IFN- $\beta$ ), and initiate downstream signaling events, such as secretion of inflammatory cytokines, chemokines, type I IFNs, and antimicrobial peptides (21). Ultimately, these responses initiate a cascade of sequestered processes, such as neutrophils recruitment, macrophage activation, and induction of IFN-stimulated genes, thereby resulting in the direct killing of pathogens $(19,21) . M t b$ is known to mediate cellular activation through TLR-2 and TLR-4. Mycobacterial lipoproteins, soluble heat-stable, and proteaseresistant factors can elicit the immune response through TLR-2 signaling, leading to apoptosis and killing of $M t b$. By contrast, heat-sensitive membrane-associated factors operate via TLR-2 and TLR-4 pathways (54-56). Also, it has been shown that TLR-4 mutant $\mathrm{C} 3 \mathrm{H} / \mathrm{HeJ}$ mice have an increased susceptibility to $M t b$ infection due to reduced macrophage recruitment and diminished pro-inflammatory cytokine responses (57). Our group has recently demonstrated that signaling through TLR-2 with its ligand Pam2Cys can rescue Th1 cells from undergoing exhaustion during chronic $M t b$ infection $(17,58)$. Furthermore, the therapeutic potential of self-adjuvanted chimeric vaccine comprising TLR-2 agonist-Pam2Cys and MHC class II binding promiscuous peptide derived from $16 \mathrm{kDa}$ antigen of $M t b$ showed a significant decline in $M t b$ burden by expanding the pool of effector as well as memory Th1 cells and Th17 cells (59). It has been reported that TLR-9 present on the APCs recognizes $M t b$-derived unmethylated $\mathrm{CpG}$, subsequently triggering a potent Th1 response (60), thus signifying the role of TLRs in controlling $M t b$ infection.

\section{C-Type Lectin Receptors}

C-type lectin receptors belong to a large superfamily of proteins containing one or more C-type lectin domains $(61,62)$. In vertebrates, CLR family is diversified into 17 subclasses. CLRs are expressed on DCs, macrophages, and NK cells that are involved in the recognition of various pathogens including $M t b$ (63-65). Some CLRs exist in a soluble form such as mannose-binding lectin (MBL), while others as transmembrane proteins such as Dectin-1. MBL is among the best-known CLRs that is found in the serum, activates the complement system, and binds to a wide range of carbohydrate motifs present on bacteria, viruses, protozoa, and fungi (66). Certain CLRs can recognize oxidized lipids and protein ligands expressed by apoptotic or necrotic cells (67-69). CLRs contain one or more extracellular carbohydrate recognition domains (CRDs), some of which contain $\mathrm{Ca}^{2+}$ binding sites. Certain amino acids in the CRD determine the carbohydrate specificity of the CLRs. It has been reported that CLRs expressing the amino acid motif EPN (Glu-Pro-Asn) in the CRD are specific to mannose-based ligands, whereas galactosespecific CLRs often express QPD (Gln-Pro-Asp) (70). The ligand specificity and the immunological signaling vary between different CLRs. For example, Dectin-1 recognizes certain $\beta$-glucan, thus initiating pro-inflammatory signaling. In addition, Clec9a binds to filamentous actin (F-actin) expressed in the necrotic cells of the body and induces cross-presentation of antigens to APCs $(62,69,71)$.

Dectin (Dectin-1 and Dectin-2) represents the archetype of non-TLRs, falling in type II transmembrane proteins. Dectin comprises extracellular CRD connected by stalk to transmembrane domain and cytosolic ITAM (immunoreceptor tyrosine activation motif) (72). Dectin is a pathogen recognition CLR expressed on macrophages, neutrophils, DCs, Langerhans cells, and the certain subset of T cells. Cells expressing Dectin recognize fungal wall-derived $\beta$-glucans and can confer protection against various infections (73). Furthermore, signaling through Dectin has been suggested to play an important role in host immunity against $M t b$. Alpha-glucan of $M t b$ is known to bind Dectin-1 receptor and promote the uptake of $M t b(73,74)$. In addition, $M t b$ induces the expression of Dectin- 1 in the epithelial cells through TLR-2 dependent signaling; leading to the production of free radicals and pro-inflammatory cytokines, such as TNF- $\alpha$, IL-6, and CXCL8 (75). Mtb-infected Dectin ${ }^{-/-}$mice showed the decline in IL-12p40 yield by DCs and, therefore, reduced immunity against $M t b$. Consequently, these studies highlight the importance of Dectin-1 in imparting immunity against the bacterium (76). Many studies suggest that binding of Man-LAM (mannose lipoarabinomannan) to Dectin-2 elicits the production of pro- and anti-inflammatory cytokines (77, 78). Furthermore, it is suggested that $M t b$-Dectin interaction activates Syk/CARD9 signaling pathway and delivers protective response (79). Upon $M t b$ infection, Dectin-1 is upregulated on alveolar macrophages, leading to respiratory burst and production of pro-inflammatory cytokines, such as IL-6, IL-12, and IL-17 $(75,80)$. Furthermore, Dectin-1 in conjunction with TLR-2 is known to play an important role in DC maturation upon infection with $M t b$ (81). It enhances reactive oxygen species production, leading to activation of various MAPKs and Src 
kinases and pro-inflammatory response against $M t b(75,82)$. By contrast, $M t b$ also employs its virulent factors, such as TDM, phosphatidylinositol, and Man-LAM, to bind to CLR and infect host cells (83). Man-LAM can suppress phagosome-lysosome fusion and help in the intracellular survival of $M t b$.

Activation of CLR induces signal transduction and gene transcription promotes phagocytosis and enhances the potential of DCs to stimulate T cells (64). The recognition of PAMP by Dectin-1, Dectin-2, and Mincle (macrophage-inducible C-type lectin) initiates kinase Syk signaling; eventually leading to NF- $\mathrm{KB}$ induced transcription $(64,66,84,85)$. Mincle and Dectin-2 recognize the gamma-chain of Fc receptor as an adaptor molecule to trigger activation of cells (84-87). DC-SIGN recognizes fucose or mannose moieties on numerous pathogens, such as $M t b$, Candida albicans, measles virus, and HIV-1, which triggers Raf-1-dependent signaling pathway and initiates TLR-induced NF- $\kappa \mathrm{B}$ activation $(88,89)$. Indeed, more in-depth studies are required to understand the interaction between CLRs and $M t b$ to decipher their role in therapeutic intervention.

\section{NOD-Like Receptors}

Recently, a family of PRRs known as nucleotide binding and oligomerization domain NLRs has gained considerable impetus following their substantial contribution in host-pathogen interaction. In the case of humans, 22 NOD molecules are reported. Their basic structure includes a central NACHT domain and a carboxy-terminal leucine-rich repeat region (90-92). The NLR proteins are cytosolic sensors for the bacterial cell wall component such as peptidoglycan $(93,94)$. One subfamily of NLRs includes NOD-1 and NOD-2, which have an amino-terminal caspase recruitment domain (CARD), essential to trigger NF- $\kappa B$ signaling. This activation leads to the enhanced release of proinflammatory cytokines (IL-1 $\beta$, IL-6, TNF, and IL-8), chemokines, nitric oxide, and antimicrobial peptides ( $\beta$-defensin 2 ). This leads to an increased expression of co-stimulatory and adhesion molecules on mononuclear cells (95-100). NOD-2 along with adaptor protein CARD9, augment MAPK, JNK, and p38 signaling pathways (101). Recently, NOD-2 has been involved in the regulation of IRF3 signaling and type I IFN production in response to the ssRNA of respiratory syncytial virus (102). The importance of NLRs family is reflected by the fact that mutations in these genes can lead to many diseases. The role of NLRs has been extensively studied in several bacterial and viral infections, inflammatory bowel disease, Crohn's disease, granulomatous inflammatory disorders, such as early onset of sarcoidosis, Blau syndrome, so on (103-105). Nonetheless, their role in TB remains inconclusive. $M t b$-infected $\mathrm{NOD}^{-2^{-/}}$mice showed impaired cytokine production by macrophages and DCs (106). Furthermore, these animals exhibited higher bacterial burden in the lungs and reduced survival due to impaired $\mathrm{T}$ cell function (107), suggesting that NOD-2 is crucial in the generation of Mtbreactive $\mathrm{T}$ cells. It may be an interesting line of investigation to study the therapeutic role of NOD-2 in bolstering T cells activity during $M t b$ infection. NOD-2 is known to act synergistically with TLR-2/TLR-4 to promote the release of inflammatory cytokines during $M t b$ infection $(108,109)$. Recently, our group has shown that activating DCs through NOD-2 and TLR-4 successfully restricted the intracellular survival of $M t b$ (16). Such DCs acquired enhanced ability to present antigen to CD4 $\mathrm{T}$ cells and CD8 T cells. These T cells exhibited improved release of IFN- $\gamma$ and TNF- $\alpha$ cytokines that play a cardinal role in protection against $M t b$. Furthermore, sustenance and expansion in the pool of memory $\mathrm{T}$ cells was noticed (110). Interestingly, adjunct therapy to treat $M t b$-infected mice using the ligand of NOD-2/ TLR- 4 with anti-TB regimen improved the efficacy of drugs by reducing the dose, without compromising their potency to kill $M t b(16)$.

\section{CYTOKINES SECRETED BY THE CELLS OF INNATE IMMUNITY ACT AS IMMUNOMODULATORS AGAINST Mtb}

Cytokines are low molecular weight glycoproteins produced by various cells of the innate and adaptive immunity. They play a paramount role in the activation and differentiation of immune cells; maintain a fine balance of homeostasis and communication network between the cells of immune system. Any disturbance in these events may instigate autoimmunity, improper protection from infectious diseases, and aberrant growth of tumors (111). Immunity can be modulated by an array of cytokines, including IL-1 $\beta$, IL-2, IL-4, IL-6, IL-10, IL-12, IL-17, IFN- $\beta$, IFN- $\gamma$, TNF- $\alpha$, and TGF- $\beta$, etc. (111). Currently, immunomodulatory role of cytokines is being exploited in various diseases. It has been suggested that IL-2- and IL-15-activated NK cells acquire potent anti-cancer activity $(112,113)$. Other examples include the role of $\alpha$-IFNs in modulating the activity of vaccine against hepatitis $B$ virus and pegylated IFNs with ribavirin for the treatment of hepatitis $\mathrm{C}$ virus (111). Recently, a synthetic form of IFN- $\alpha 2 b$ known as Infergen showed a potent immunomodulatory activity against $M t b$, by the activation of macrophages, induction of autophagy and inhibition of the growth of $M t b$ (114). It is well known that cytokines can aptly improve the efficacy of vaccines. Co-administration of memory enhancing cytokines IL-7 and IL-15 substantially augmented the efficacy of BCG by eliciting enduring memory $\mathrm{T}$ cells and protection against $\mathrm{Mtb}$ (115). Similarly, IL-1, IL-6, and TNF- $\alpha$ bolstered BCG potency by generating long-lasting protective memory $\mathrm{T}$ cell response (116). Thus, it would be quite interesting to develop a recombinant BCG expressing memory enhancing cytokines. This strategy would improve the efficacy of BCG in protecting not only childhood but also the adult manifestation of TB. It is worth to mention here that BCG protects only children against TB but its efficacy wanes with the age (117).

\section{MICROBIAL PRODUCTS}

In 1885, Louis Pasteur hypothesized that microbes possess immunogenic components. These microbial products include several molecules that can be sensed by the PRRs of the host to alert the cells of the immune system (118). Triggering of DCs and macrophages by the microbial PAMPs releases numerous cytokines and chemokines. MDP of $M t b$ is endowed with adjuvant properties since it can bind to NOD-2 of host cells and 
boosts their function $(16,109,119)$. Furthermore, monophosphoryl lipid A (MLA), a lipopolysaccharide component of Gramnegative bacteria cell wall is an agonist of TLR-4. MLA has been established to possess adjuvant activity and induces the immune response to heterologous proteins, making it an integral part of vaccines and immunotherapeutics $(120,121)$. The unmethylated CpG of $M t b$ recognized by TLR- 9 activates Th1 cells preferentially $(60,122)$. Likewise, glucans, zymosan, lentinans, and aminated poly glucose of yeast activate macrophages and provide optimum antimicrobial immunity to the host. The bacterial lipoproteins act as a potent adjuvant by delivering danger signal through TLR-1/2, which stimulates the production of IL-1, IL-6, TNF- $\alpha$, and NO by monocytes and macrophages, which ultimately strengthen the immunity (123). Many subunit vaccines against intracellular pathogens fail to reach clinical trials due to the non-availability of adjuvants that can be approved for human use. Microbial-derived adjuvants efficiently evoke the cell-mediated immune response (124-126). In addition, they are highly stable and less toxic (123), making them suitable for human use; especially for vaccines against TB and HIV.

\section{SYNTHETIC CHEMICAL COMPOUNDS}

A wide array of microbial components is known to induce immunomodulatory activities (127). In past, these agents have been successfully used in designing or modifying potent vaccine candidates and drugs against pathogens and inflammatory responses (128). These synthetic compounds include mono- and multivalent galabiose derivatives, glycol-dendrimers, galactose-dendrimers, glycopeptide-dendrimers, and multivalent glycosylated fullerenes, which elicits a potent immunogenic activity (129). Microbes also possess certain essential cell surface carbohydrates, glycoconjugates, and oligosaccharides; which fundamentally help in the cell growth, proliferation, and cell-cell interactions. These molecules are well recognized by parenchymal cells, endothelial cells, and immune cells as they express specific PRRs to recognize microbial components. Chemically synthesized analogs of these microbial components, such as MLA, have been identified as potent immunomodulatory compounds that can enhance immunity and act as adjuvant for several vaccines (121).

\section{ROLE OF VITAMIN D3 AS A POTENTIAL IMMUNOMODULATOR IN TB TREATMENT}

1,25-Dihydroxyvitamin D3 (VD3) has been reported for inducing host resistance against TB. VD3 has been used as a mode of treatment during the early pre-antibiotic age. VD3 acts through its receptor and its genetic polymorphisms have been linked with susceptibility or resistance to TB. Recent studies demonstrate that VD3 boosts innate immunity by improving the expression of various antimicrobial peptides and induction of autophagy that ultimately restricts the intracellular growth of $M t b$. Furthermore, VD3 has been involved in coordination with various pro-inflammatory cytokines, such as IL-15, IL-32, and IFN- $\gamma$, to control TB $(130,131)$. Various clinical trials have assessed VD3 as a probable candidate for adjunct therapy to treat TB $(132,133)$. Henceforth, a combinatorial therapy of VD3 and anti-TB drugs may be a novel therapeutic strategy to treat patients suffering from TB.

\section{INHIBITION OF IMMUNE CHECKPOINTS}

Recently, antibody therapy to block the function of checkpoint inhibitors, such as the programmed cell death-1 (PD-1) and cytotoxic T-lymphocyte-associated antigen 4 (CTLA-4), has gained substantial importance in overcoming the suppression induced by these molecules. Some clinical studies indicate a potential contribution of the $\mathrm{PD}-1 / \mathrm{PD}-\mathrm{L} 1$ pathway in the progression of TB pathogenesis. PD-L1 is constitutively expressed on the macrophages of patients infected with $M t b$ (134). Blockade of PD-L1 with its monoclonal antibodies enhances IFN- $\gamma$ production by $\mathrm{T}$ cells and help to control the growth of $M t b$ in pulmonary TB patients $(134,135)$. Furthermore, PD-1 expressed on the surface of regulatory T cells (Tregs), neutrophils, and NKT cells control the inflammatory response, avoiding damage done to patient tissues (136-139). It has been demonstrated that CTLA-4 is equally expressed by effector T cells and Tregs isolated from the blood of active TB patients, which may be important in maintaining the optimum immune response $(136,140,141)$.

Another immune checkpoint, lymphocyte-activation gene-3 (LAG-3), is commonly expressed by Tregs cells. Blocking of LAG-3 modulates CD4 $\mathrm{T}$ cells response and avoids $\mathrm{T}$ cell exhaustion (142). Recently, LAG-3 has been shown to be highly expressed in the lungs of patients suffering from active TB but not in latent infection (143). In addition, T cell immunoglobulin and mucin domain-3 (TIM-3) bind to galectin 9 (Gal9) on the surface of APCs. Blocking of TIM-3 prevents apoptosis of $M t b$-reactive effector T cells (144). In vitro TIM-3 blockade in co-culture experiments with $M t b$-infected macrophages and T cells isolated from TB patients fostered bacterial killing by enhancing IL-1 $\beta$ secretion by macrophages along with IFN- $\gamma$ release by $\mathrm{T}$ cells $(145,146)$. Neutralization of the activity of TIM- 3 and PD-1 by their respective antibodies resulted in enhanced $\mathrm{T}$ cells response and reduction of $M t b$ burden in the macrophages obtained from HIV-TB patients (146). These studies suggest that blocking of immuno-checkpoint molecules significantly improve the immunity of the host. It may be an interesting line of investigation to treat TB patients with drugs while boosting their immunity by blocking the function of immune checkpoint molecules by their respective antibodies.

\section{IMMUNOMODULATION THROUGH PRRS: AN APPROACH TO OVERCOME DRUG RESISTANCE IN Mtb}

Recent reports from WHO reveals that antibiotic treatment will not be successful beyond 2020 due to the emergence of totally drug-resistant strains of $M t b$ (147-149). Drug-resistant strains of $M t b$ have evolved to evade antibiotic treatment by several mechanisms, including efflux pumps, mutations of antibiotic target proteins, and development of enzymes that degrade the active moieties of an antibiotic (150-157). Lengthy drug treatment is required to clear the $M t b$ infection. The excessive 
and prolonged use of anti-TB drugs is a major contributor in promoting the development of drug resistance. Stimulating the host cells through PRRs can overcome this problem. It is now a well-established fact that signaling through PRRs can optimally activate the cells of both innate and adaptive immunity (15-18). Signaling delivered through PRRs can augment APC capacity to sense and phagocytose $M t b$ followed by processing and presentation of its antigens to $\mathrm{T}$ cells. This process is essential for the clearance of infection (15). A combinatorial therapy to stimulate the immune system by immunomodulators and drugs to kill $M t b$ in a concerted fashion can substantially control the development of drug resistance and will help to reduce the dose and duration of treatment. Furthermore, it will overcome the toxicity and immunosuppression that are associated with current regimen.

The challenge still remains to identify the appropriate agonists of PRRs that can deliver optimum response against $M t b$ (Figure 3). This may require extensive investigation to select the most potent PRRs from different TLRs (TLR-2, TLR-4, and TLR-9), NLRs (NOD-1, NOD-2), and CLRs (Mincle, Dectin-1, and Dectin-2) $(15,30-35,158)$. In this context, an elegant study conducted in the experimental model of TB has indicated that adjunct therapy involving agonist of NOD-2 and TLR-4 can reduce the dose of anti-TB drugs (16). It will be an interesting line of future investigation to study the potency of NOD-2 and TLR-4 in TB patients to shorten the current treatment.

\section{PRECAUTIONS WHILE MODULATING THE IMMUNE SYSTEM}

In this article, several advantages of stimulating the immune system through molecules of innate immunity have been discussed. However, side-effects that can incur due to hyperactivation of the immune systems, such as inflammatory responses and tissue damage, cannot be totally denied. Such therapies cannot be given to individuals suffering from neurodegenerative diseases, arthritis, asthma, inflammatory bowel disease, or lung fibrosis (159). Furthermore, cryptic antigens released by hyperactivation of the immune system may break immune tolerance, leading to undesired activation and proliferation of autoreactive $\mathrm{T}$ cells and B cells, eventually culminating into autoimmune diseases (160). Furthermore, the excessive release of pro-inflammatory cytokines and free radicals will damage host tissues, as observed in the case of sepsis $(148,158,161-166)$. Similarly, over stimulation can have adverse side-effects on individuals suffering from allergies, autoimmune diseases, and inflammatory disorders. It is crucial to take into consideration immune status of TB patients while treating them with immunomodulators for controlling $M t b$ infection. Consequently, understanding the history of the patient will be important before practicing such therapies. Therefore, to deliver maximum benefit, immunomodulators should be used in a form of a personalized medicine.

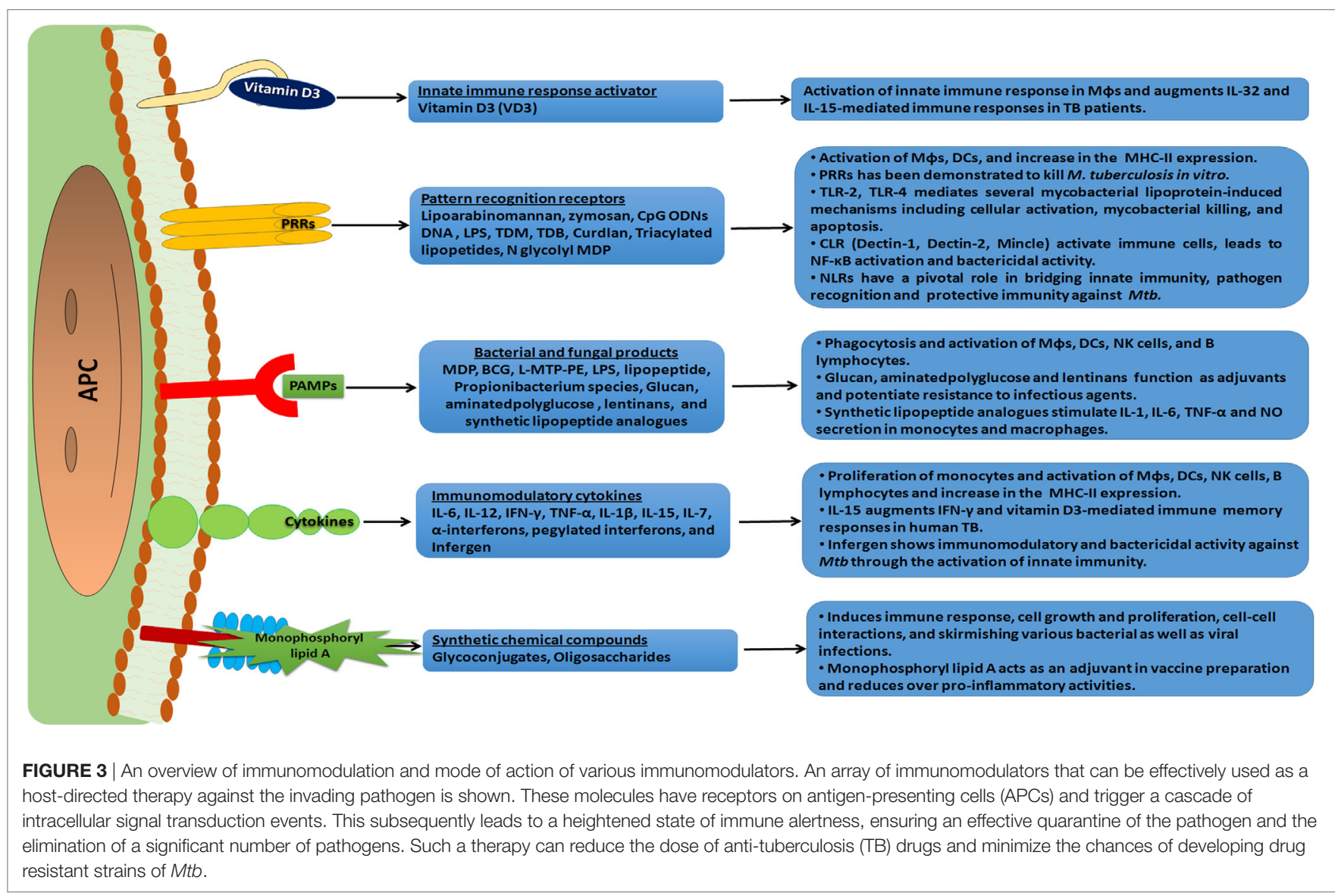


The inflammatory responses generated through immunomodulation can be well controlled by careful titration of the dose of an immunomodulator. One of the possibility is to administer the immunomodulators through nasal route at the site of infection i.e., lungs during TB infection. This will elicit local immunity that is crucial to combat $M t b$ without provoking the undesirable activation of systemic immunity. In this context, a detailed and broad spectrum pharmacological study to decipher any adverse effect of immunomodulatory therapy with other drugs is of paramount importance. Importantly, a particular immunomodulator may not be potent against all pathogens. Therefore, it requires a thorough examination of its efficacy against certain pathogens. Despite these limitations, immunomodulation can be quite effective because it targets the host rather than the pathogen, thus avoiding the chance of evolving drug resistance in microbes. In addition, boosting innate immunity offers an advantage of providing protection against an array of pathogens. Furthermore, in combination with the standard drugs, it can minimize the sideeffects; and reduce the dose and duration of lengthy TB regime.

\section{THERAPEUTIC INTERVENTION}

Despite of the fact that potent drugs are available to treat $\mathrm{TB}$, the disease continues to devastate human lives. Furthermore, lengthy drug regime provides sufficient time and opportunity for the bacteria to develop drug resistance. Furthermore, the situation is complicated due to AIDS-pandemic and non-compliance of BCG vaccine to protect from the disease $(117,167)$. Therefore, there is an urgent need and challenge for the scientific community to devise and develop alternative means to treat $\mathrm{TB}$ patients. In this regard, one of the promising and novel approaches can be "host-directed therapy," by

\section{REFERENCES}

1. World Health Organization. Global Tuberculosis Report 2016. (2016).

2. Barry CE III, Boshoff HI, Dartois V, Dick T, Ehrt S, Flynn J, et al. The spectrum of latent tuberculosis: rethinking the biology and intervention strategies. Nat Rev Microbiol (2009) 7(12):845-55. doi:10.1038/nrmicro2236

3. Ottenhoff TH, Kaufmann SH. Vaccines against tuberculosis: where are we and where do we need to go? PLoS Pathog (2012) 8(5):e1002607. doi:10.1371/ journal.ppat.1002607

4. Kaufmann SH. Tuberculosis vaccines: time to think about the next generation. Semin Immunol (2013) 25(2):172-81. doi:10.1016/j.smim.2013. 04.006

5. Dye C, Williams BG, Espinal MA, Raviglione MC. Erasing the world's slow stain: strategies to beat multidrug-resistant tuberculosis. Science (2002) 295(5562):2042-6. doi:10.1126/science.1063814

6. Arbex MA, Varella Mde C, Siqueira HR, Mello FA. Antituberculosis drugs: drug interactions, adverse effects, and use in special situations. Part 1: first-line drugs. J Bras Pneumol (2010) 36(5):626-40. doi:10.1590/ S1806-37132010000500016

7. Kaufmann SH, Lange C, Rao M, Balaji KN, Lotze M, Schito M, et al. Progress in tuberculosis vaccine development and host-directed therapies - a state of the art review. Lancet Respir Med (2014) 2(4):301-20. doi:10.1016/ S2213-2600(14)70033-5

8. Zumla A, Rao M, Dodoo E, Maeurer M. Potential of immunomodulatory agents as adjunct host-directed therapies for multidrug-resistant tuberculosis. BMC Med (2016) 14:89. doi:10.1186/s12916-016-0635-1

9. Gupta A, Misra A, Deretic V. Targeted pulmonary delivery of inducers of host macrophage autophagy as a potential host-directed chemotherapy exploiting the potential of PRRs to elicit anti-TB immunity. Such a strategy can be explored as an adjunct therapy with the drugs to reduce the dose and duration of treatment. In addition, this approach will have added advantage in controlling the emergence of drug resistance in $M t b$ by eliciting host immunity, thereby increasing the potency of drugs. Additionally, in the age of "one world one health one medicine" theory, the persuasive utilization of immunomodulators can be considered as an exclusive and alternative means to treat patients suffering from many infections.

\section{AUTHOR CONTRIBUTIONS}

The designing of theme and concept were done by JA and SP. The figures and manuscript were prepared and written by SP, GK, MA, SN, DC, HB, SS, and JA.

\section{ACKNOWLEDGMENTS}

This study is supported by the Council of Scientific and Industrial Research (CSIR), New Delhi, India. SP, GK, DC, and HB are the recipient of the Fellowship of Council of Scientific and Industrial Research; SN of Department of Biotechnology; MA of Department of Science and Technology, and SS of Indian Council of Medical Research. We are thankful to Barry T. Rouse, Professor at the Biomedical and Diagnostic Sciences and Viral Immunology Section, The College of Veterinary Medicine, University of Tennessee, Knoxville, TN, USA; Phillip P. Domeier, Department of Microbiology and Immunology, Pennsylvania State University College of Medicine, Hershey, PA, and Sean Campbell, Immunology and Microbiology, Scripps, Florida, for critically evaluating the manuscript.

of tuberculosis. Adv Drug Deliv Rev (2016) 102:10-20. doi:10.1016/j. addr.2016.01.016

10. Zumla A, Rao M, Wallis RS, Kaufmann SH, Rustomjee R, Mwaba P, et al. Host-directed therapies for infectious diseases: current status, recent progress, and future prospects. Lancet Infect Dis (2016) 16(4):e47-63. doi:10.1016/ S1473-3099(16)00078-5

11. Khan N, Gowthaman U, Pahari S, Agrewala JN. Manipulation of costimulatory molecules by intracellular pathogens: veni, vidi, vici!! PLoS Pathog (2012) 8(6):e1002676. doi:10.1371/journal.ppat.1002676

12. Stenger S, Modlin RL. T cell mediated immunity to Mycobacterium tuberculosis. Curr Opin Microbiol (1999) 2(1):89-93. doi:10.1016/ S1369-5274(99)80015-0

13. Janeway CA Jr. Approaching the asymptote? Evolution and revolution in immunology. Cold Spring Harb Symp Quant Biol (1989) 54(Pt 1):1-13. doi:10.1101/SQB.1989.054.01.003

14. Turvey SE, Broide DH. Innate immunity. J Allergy Clin Immunol (2010) 125 (2 Suppl 2):S24-32. doi:10.1016/j.jaci.2009.07.016

15. Khan N, Pahari S, Vidyarthi A, Aqdas M, Agrewala JN. Stimulation through CD40 and TLR-4 is an effective host directed therapy against Mycobacterium tuberculosis. Front Immunol (2016) 7:386. doi:10.3389/fimmu.2016.00386

16. Khan N, Pahari S, Vidyarthi A, Aqdas M, Agrewala JN. NOD-2 and TLR-4 signaling reinforces the efficacy of dendritic cells and reduces the dose of TB drugs against Mycobacterium tuberculosis. J Innate Immun (2016) 8(3):228-42. doi:10.1159/000439591

17. Chodisetti SB, Gowthaman U, Rai PK, Vidyarthi A, Khan N, Agrewala JN. Triggering through toll-like receptor 2 limits chronically stimulated T-helper type 1 cells from undergoing exhaustion. J Infect Dis (2015) 211(3):486-96. doi:10.1093/infdis/jiu472 
18. Gowthaman U, Singh V, Zeng W, Jain S, Siddiqui KF, Chodisetti SB, et al. Promiscuous peptide of $16 \mathrm{kDa}$ antigen linked to Pam2Cys protects against Mycobacterium tuberculosis by evoking enduring memory T-cell response. J Infect Dis (2011) 204(9):1328-38. doi:10.1093/infdis/jir548

19. Mogensen TH. Pathogen recognition and inflammatory signaling in innate immune defenses. Clin Microbiol Rev (2009) 22(2):240-73, Table of Contents. doi:10.1128/CMR.00046-08

20. Hoebe K, Janssen E, Beutler B. The interface between innate and adaptive immunity. Nat Immunol (2004) 5(10):971-4. doi:10.1038/ni1004-971

21. Kawai T, Akira S. The role of pattern-recognition receptors in innate immunity: update on toll-like receptors. Nat Immunol (2010) 11(5):373-84. doi:10.1038/ni.1863

22. Krishnaswamy JK, Chu T, Eisenbarth SC. Beyond pattern recognition: NOD-like receptors in dendritic cells. Trends Immunol (2013) 34(5):224-33. doi:10.1016/j.it.2012.12.003

23. Morrison J, Pai M, Hopewell PC. Tuberculosis and latent tuberculosis infection in close contacts of people with pulmonary tuberculosis in low-income and middle-income countries: a systematic review and meta-analysis. Lancet Infect Dis (2008) 8(6):359-68. doi:10.1016/S1473-3099(08)70071-9

24. Verrall AJ, Netea MG, Alisjahbana B, Hill PC, van Crevel R. Early clearance of Mycobacterium tuberculosis: a new frontier in prevention. Immunology (2014) 141(4):506-13. doi:10.1111/imm.12223

25. Riedel DD, Kaufmann SH. Chemokine secretion by human polymorphonuclear granulocytes after stimulation with Mycobacterium tuberculosis and lipoarabinomannan. Infect Immun (1997) 65(11):4620-3.

26. Harriff MJ, Cansler ME, Toren KG, Canfield ET, Kwak S, Gold MC, et al. Human lung epithelial cells contain Mycobacterium tuberculosis in a late endosomal vacuole and are efficiently recognized by CD8(+) T cells. PLoS One (2014) 9(5):e97515. doi:10.1371/journal.pone.0097515

27. von Garnier C, Filgueira L, Wikstrom M, Smith M, Thomas JA, Strickland DH, et al. Anatomical location determines the distribution and function of dendritic cells and other APCs in the respiratory tract. J Immunol (2005) 175(3):1609-18. doi:10.4049/jimmunol.175.3.1609

28. Meraviglia S, El Daker S, Dieli F, Martini F, Martino A. gammadelta T cells cross-link innate and adaptive immunity in Mycobacterium tuberculosis infection. Clin Dev Immunol (2011) 2011:587315. doi:10.1155/2011/ 587315

29. Steinman RM. Linking innate to adaptive immunity through dendritic cells. Novartis Found Symp (2006) 279:101-9; discussion 109-13, 216-219. doi:10.1002/9780470035399.ch9

30. Kleinnijenhuis J, Oosting M, Joosten LA, Netea MG, Van Crevel R. Innate immune recognition of Mycobacterium tuberculosis. Clin Dev Immunol (2011) 2011:405310. doi:10.1155/2011/405310

31. Kumar H, Kawai T, Akira S. Pathogen recognition by the innate immune system. Int Rev Immunol (2011) 30(1):16-34. doi:10.3109/08830185.2010. 529976

32. van Crevel $\mathrm{R}$, Ottenhoff $\mathrm{TH}$, van der Meer JW. Innate immunity to Mycobacterium tuberculosis. Clin Microbiol Rev (2002) 15(2):294-309. doi:10.1128/CMR.15.2.294-309.2002

33. Mortaz E, Adcock IM, Tabarsi P, Masjedi MR, Mansouri D, Velayati AA, et al. Interaction of pattern recognition receptors with Mycobacterium tuberculosis. J Clin Immunol (2015) 35(1):1-10. doi:10.1007/s10875-014-0103-7

34. Kerscher B, Willment JA, Brown GD. The dectin-2 family of C-type lectin-like receptors: an update. Int Immunol (2013) 25(5):271-7. doi:10.1093/ intimm/dxt006

35. Steinman RM, Hemmi H. Dendritic cells: translating innate to adaptive immunity. Curr Top Microbiol Immunol (2006) 311:17-58.

36. Lugton I. Mucosa-associated lymphoid tissues as sites for uptake, carriage and excretion of tubercle bacilli and other pathogenic mycobacteria. Immunol Cell Biol (1999) 77(4):364-72. doi:10.1046/j.1440-1711.1999.00836.x

37. Balu S, Reljic R, Lewis MJ, Pleass RJ, McIntosh R, van Kooten C, et al. A novel human IgA monoclonal antibody protects against tuberculosis. J Immunol (2011) 186(5):3113-9. doi:10.4049/jimmunol.1003189

38. Tamura S, Kurata T. Defense mechanisms against influenza virus infection in the respiratory tract mucosa. Jpn J Infect Dis (2004) 57(6):236-47.

39. Holmgren J, Svennerholm AM. Vaccines against mucosal infections. Curr Opin Immunol (2012) 24(3):343-53. doi:10.1016/j.coi.2012. 03.014
40. Wu RQ, Zhang DF, Tu E, Chen QM, Chen W. The mucosal immune system in the oral cavity-an orchestra of T cell diversity. Int J Oral Sci (2014) 6(3):125-32. doi:10.1038/ijos.2014.48

41. Price DN, Kusewitt DF, Lino CA, McBride AA, Muttil P. Oral tolerance to environmental mycobacteria interferes with intradermal, but not pulmonary, immunization against tuberculosis. PLoS Pathog (2016) 12(5):e1005614. doi:10.1371/journal.ppat.1005614

42. Belkaid Y, Hand TW. Role of the microbiota in immunity and inflammation. Cell (2014) 157(1):121-41. doi:10.1016/j.cell.2014.03.011

43. Corthesy B, Gaskins HR, Mercenier A. Cross-talk between probiotic bacteria and the host immune system. J Nutr (2007) 137(3 Suppl 2):781S-90S.

44. del Rio B, Dattwyler RJ, Aroso M, Neves V, Meirelles L, Seegers JF, et al. Oral immunization with recombinant Lactobacillus plantarum induces a protective immune response in mice with Lyme disease. Clin Vaccine Immunol (2008) 15(9):1429-35. doi:10.1128/CVI.00169-08

45. Devine DA, Marsh PD, Meade J. Modulation of host responses by oral commensal bacteria. J Oral Microbiol (2015) 7:26941. doi:10.3402/jom. v7.26941

46. Soloff AC, Barratt-Boyes SM. Enemy at the gates: dendritic cells and immunity to mucosal pathogens. Cell Res (2010) 20(8):872-85. doi:10.1038/cr.2010.94

47. Blecha F. Immunomodulators for prevention and treatment of infectious diseases in food-producing animals. Vet Clin North Am Food Anim Pract (2001) 17(3):621-33, viii. doi:10.1016/S0749-0720(15)30010-4

48. Wilson-Welder JH, Torres MP, Kipper MJ, Mallapragada SK, Wannemuehler MJ, Narasimhan B. Vaccine adjuvants: current challenges and future approaches. J Pharm Sci (2009) 98(4):1278-316. doi:10.1002/ jps. 21523

49. Jin C, Flavell RA. Innate sensors of pathogen and stress: linking inflammation to obesity. J Allergy Clin Immunol (2013) 132(2):287-94. doi:10.1016/j. jaci.2013.06.022

50. Konner AC, Bruning JC. Toll-like receptors: linking inflammation to metabolism. Trends Endocrinol Metab (2011) 22(1):16-23. doi:10.1016/j. tem.2010.08.007

51. Eisenberg SP, Brewer MT, Verderber E, Heimdal P, Brandhuber BJ, Thompson RC. Interleukin 1 receptor antagonist is a member of the interleukin 1 gene family: evolution of a cytokine control mechanism. Proc Natl Acad Sci U S A (1991) 88(12):5232-6. doi:10.1073/pnas.88.12.5232

52. Kuroki Y, Takahashi M, Nishitani C. Pulmonary collectins in innate immunity of the lung. Cell Microbiol (2007) 9(8):1871-9. doi:10.1111/j.1462-5822.2007.00953.x

53. Akira S. TLR signaling. Curr Top Microbiol Immunol (2006) 311:1-16.

54. Underhill DM, Ozinsky A, Smith KD, Aderem A. Toll-like receptor-2 mediates mycobacteria-induced proinflammatory signaling in macrophages. Proc Natl Acad Sci U S A (1999) 96(25):14459-63. doi:10.1073/pnas.96. 25.14459

55. Thoma-Uszynski S, Kiertscher SM, Ochoa MT, Bouis DA, Norgard MV, Miyake K, et al. Activation of toll-like receptor 2 on human dendritic cells triggers induction of IL-12, but not IL-10. J Immunol (2000) 165(7):3804-10. doi:10.4049/jimmunol.165.7.3804

56. Brightbill HD, Libraty DH, Krutzik SR, Yang RB, Belisle JT, Bleharski JR, et al. Host defense mechanisms triggered by microbial lipoproteins through toll-like receptors. Science (1999) 285(5428):732-6. doi:10.1126/ science.285.5428.732

57. Abel B, Thieblemont N, Quesniaux VJ, Brown N, Mpagi J, Miyake K, et al. Toll-like receptor 4 expression is required to control chronic Mycobacterium tuberculosis infection in mice. J Immunol (2002) 169(6):3155-62. doi:10.4049/ jimmunol.169.6.3155

58. Khan N, Vidyarthi A, Amir M, Mushtaq K, Agrewala JN. T-cell exhaustion in tuberculosis: pitfalls and prospects. Crit Rev Microbiol (2017) 43(2):133-41. doi:10.1080/1040841X.2016.1185603

59. Rai PK, Chodisetti SB, Nadeem S, Maurya SK, Gowthaman U, Zeng W, et al. A novel therapeutic strategy of lipidated promiscuous peptide against Mycobacterium tuberculosis by eliciting Th1 and Th17 immunity of host. Sci Rep (2016) 6:23917. doi:10.1038/srep23917

60. Bafica A, Scanga CA, Feng CG, Leifer C, Cheever A, Sher A. TLR9 regulates Th1 responses and cooperates with TLR2 in mediating optimal resistance to Mycobacterium tuberculosis. J Exp Med (2005) 202(12):1715-24. doi:10.1084/ jem.20051782 
61. Drickamer K. C-type lectin-like domains. Curr Opin Struct Biol (1999) 9(5):585-90. doi:10.1016/S0959-440X(99)00009-3

62. Zelensky AN, Gready JE. The C-type lectin-like domain superfamily. FEBS J (2005) 272(24):6179-217. doi:10.1111/j.1742-4658.2005.05031.x

63. Geijtenbeek TB, van Vliet SJ, Engering A, t Hart BA, van Kooyk Y. Self- and nonself-recognition by C-type lectins on dendritic cells. Annu Rev Immunol (2004) 22:33-54. doi:10.1146/annurev.immunol.22.012703.104558

64. Kerrigan AM, Brown GD. Syk-coupled C-type lectins in immunity. Trends Immunol (2011) 32(4):151-6. doi:10.1016/j.it.2011.01.002

65. Robinson MJ, Sancho D, Slack EC, LeibundGut-Landmann S, Reis e Sousa C. Myeloid C-type lectins in innate immunity. Nat Immunol (2006) 7(12):1258-65. doi:10.1038/ni1417

66. Yamasaki S, Matsumoto M, Takeuchi O, Matsuzawa T, Ishikawa E, Sakuma M, et al. C-type lectin Mincle is an activating receptor for pathogenic fungus, Malassezia. Proc Natl Acad Sci U S A (2009) 106(6):1897-902. doi:10.1073/pnas.0805177106

67. Sancho D, Joffre OP, Keller AM, Rogers NC, Martinez D, HernanzFalcon $\mathrm{P}$, et al. Identification of a dendritic cell receptor that couples sensing of necrosis to immunity. Nature (2009) 458(7240):899-903. doi:10.1038/ nature 07750

68. Tel J, Benitez-Ribas D, Hoosemans S, Cambi A, Adema GJ, Figdor CG, et al. DEC-205 mediates antigen uptake and presentation by both resting and activated human plasmacytoid dendritic cells. Eur J Immunol (2011) 41(4):1014-23. doi:10.1002/eji.201040790

69. Geijtenbeek TB. Actin' as a death signal. Immunity (2012) 36(4):557-9. doi:10.1016/j.immuni.2012.04.004

70. Sancho D, Reis e Sousa C. Signaling by myeloid C-type lectin receptors in immunity and homeostasis. Annu Rev Immunol (2012) 30:491-529. doi:10.1146/annurev-immunol-031210-101352

71. Ahrens S, Zelenay S, Sancho D, Hanc P, Kjaer S, Feest C, et al. F-actin is an evolutionarily conserved damage-associated molecular pattern recognized by DNGR-1, a receptor for dead cells. Immunity (2012) 36(4):635-45. doi:10.1016/j.immuni.2012.03.008

72. Gross O, Gewies A, Finger K, Schafer M, Sparwasser T, Peschel C, et al. Card9 controls a non-TLR signalling pathway for innate anti-fungal immunity. Nature (2006) 442(7103):651-6. doi:10.1038/nature04926

73. Yadav M, Schorey JS. The beta-glucan receptor dectin-1 functions together with TLR2 to mediate macrophage activation by mycobacteria. Blood (2006) 108(9):3168-75. doi:10.1182/blood-2006-05-024406

74. Zenaro E, Donini M, Dusi S. Induction of Th1/Th17 immune response by Mycobacterium tuberculosis: role of dectin-1, mannose receptor, and DC-SIGN. J Leukoc Biol (2009) 86(6):1393-401. doi:10.1189/jlb.0409242

75. Lee HM, Yuk JM, Shin DM, Jo EK. Dectin-1 is inducible and plays an essential role for mycobacteria-induced innate immune responses in airway epithelial cells. J Clin Immunol (2009) 29(6):795-805. doi:10.1007/ s10875-009-9319-3

76. Rothfuchs AG, Bafica A, Feng CG, Egen JG, Williams DL, Brown GD, et al. Dectin-1 interaction with Mycobacterium tuberculosis leads to enhanced IL-12p40 production by splenic dendritic cells. J Immunol (2007) 179(6):3463-71. doi:10.4049/jimmunol.179.6.3463

77. Fratti RA, Chua J, Vergne I, Deretic V. Mycobacterium tuberculosis glycosylated phosphatidylinositol causes phagosome maturation arrest. Proc Natl Acad Sci U S A (2003) 100(9):5437-42. doi:10.1073/pnas.0737613100

78. Yonekawa A, Saijo S, Hoshino Y, Miyake Y, Ishikawa E, Suzukawa M, et al. Dectin-2 is a direct receptor for mannose-capped lipoarabinomannan of mycobacteria. Immunity (2014) 41(3):402-13. doi:10.1016/j. immuni.2014.08.005

79. Dorhoi A, Desel C, Yeremeev V, Pradl L, Brinkmann V, Mollenkopf HJ, et al. The adaptor molecule CARD9 is essential for tuberculosis control. J Exp Med (2010) 207(4):777-92. doi:10.1084/jem.20090067

80. Reid DM, Gow NA, Brown GD. Pattern recognition: recent insights from dectin-1. Curr Opin Immunol (2009) 21(1):30-7. doi:10.1016/j.coi.2009.01.003

81. Romero MM, Basile JI, Corra Feo L, Lopez B, Ritacco V, Aleman M. Reactive oxygen species production by human dendritic cells involves TLR2 and dectin-1 and is essential for efficient immune response against mycobacteria. Cell Microbiol (2016) 18(6):875-86. doi:10.1111/cmi.12562

82. Shin DM, Yang CS, Yuk JM, Lee JY, Kim KH, Shin SJ, et al. Mycobacterium abscessus activates the macrophage innate immune response via a physical and functional interaction between TLR2 and dectin-1. Cell Microbiol (2008) 10(8):1608-21. doi:10.1111/j.1462-5822.2008.01151.x

83. Mishra AK, Driessen NN, Appelmelk BJ, Besra GS. Lipoarabinomannan and related glycoconjugates: structure, biogenesis and role in Mycobacterium tuberculosis physiology and host-pathogen interaction. FEMS Microbiol Rev (2011) 35(6):1126-57. doi:10.1111/j.1574-6976.2011.00276.x

84. Rogers NC, Slack EC, Edwards AD, Nolte MA, Schulz O, Schweighoffer E, et al. Syk-dependent cytokine induction by dectin-1 reveals a novel pattern recognition pathway for C type lectins. Immunity (2005) 22(4):507-17. doi:10.1016/j.immuni.2005.06.005

85. Sato K, Yang XL, Yudate T, Chung JS, Wu J, Luby-Phelps K, et al. Dectin-2 is a pattern recognition receptor for fungi that couples with the $\mathrm{Fc}$ receptor gamma chain to induce innate immune responses. JBiol Chem (2006) 281(50):38854-66. doi:10.1074/jbc.M606542200

86. Yamasaki S. [Mincle, as a sensor for damaged cells]. Tanpakushitsu Kakusan Koso (2009) 54(8 Suppl):1125-9.

87. Ishikawa E, Ishikawa T, Morita YS, Toyonaga K, Yamada H, Takeuchi O, et al. Direct recognition of the mycobacterial glycolipid, trehalose dimycolate, by C-type lectin Mincle. J Exp Med (2009) 206(13):2879-88. doi:10.1084/ jem. 20091750

88. Gringhuis SI, den Dunnen J, Litjens M, van Het Hof B, van Kooyk Y, GeijtenbeekTB.C-typelectinDC-SIGNmodulatestoll-likereceptorsignaling via Raf-1 kinase-dependent acetylation of transcription factor NF-kappaB. Immunity (2007) 26(5):605-16. doi:10.1016/j.immuni.2007.03.012

89. Geijtenbeek TB, den Dunnen J, Gringhuis SI. Pathogen recognition by DC-SIGN shapes adaptive immunity. Future Microbiol (2009) 4(7):879-90. doi:10.2217/fmb.09.51

90. Franchi L, Park JH, Shaw MH, Marina-Garcia N, Chen G, Kim YG, et al. Intracellular NOD-like receptors in innate immunity, infection and disease. Cell Microbiol (2008) 10(1):1-8. doi:10.1111/j.1462-5822.2007.01059.x

91. Fritz JH, Ferrero RL, Philpott DJ, Girardin SE. NOD-like proteins in immunity, inflammation and disease. Nat Immunol (2006) 7(12):1250-7. doi:10.1038/ni1412

92. Werts C, Girardin SE, Philpott DJ. TIR, CARD and PYRIN: three domains for an antimicrobial triad. Cell Death Differ (2006) 13(5):798-815. doi:10.1038/sj.cdd. 4401890

93. Girardin SE, Boneca IG, Viala J, Chamaillard M, Labigne A, Thomas G, et al. NOD2 is a general sensor of peptidoglycan through muramyl dipeptide (MDP) detection. J Biol Chem (2003) 278(11):8869-72. doi:10.1074/jbc. C200651200

94. Girardin SE, Travassos LH, Herve M, Blanot D, Boneca IG, Philpott DJ, et al. Peptidoglycan molecular requirements allowing detection by NOD1 and NOD2. J Biol Chem (2003) 278(43):41702-8. doi:10.1074/jbc. M307198200

95. Chin AI, Dempsey PW, Bruhn K, Miller JF, Xu Y, Cheng G. Involvement of receptor-interacting protein 2 in innate and adaptive immune responses. Nature (2002) 416(6877):190-4. doi:10.1038/416190a

96. Uehara A, Fujimoto Y, Fukase K, Takada H. Various human epithelial cells express functional toll-like receptors, NOD1 and NOD2 to produce antimicrobial peptides, but not proinflammatory cytokines. Mol Immunol (2007) 44(12):3100-11. doi:10.1016/j.molimm.2007.02.007

97. Guo LH, Guo KT, Wendel HP, Schluesener HJ. Combinations of TLR and NOD2 ligands stimulate rat microglial P2X4R expression. Biochem Biophys Res Commun (2006) 349(3):1156-62. doi:10.1016/j.bbrc.2006.08.146

98. Kramer M, Netea MG, de Jong DJ, Kullberg BJ, Adema GJ. Impaired dendritic cell function in Crohn's disease patients with NOD2 3020insC mutation. J Leukoc Biol (2006) 79(4):860-6. doi:10.1189/jlb.0805484

99. Heinzelmann M, Polk HC Jr, Chernobelsky A, Stites TP, Gordon LE. Endotoxin and muramyl dipeptide modulate surface receptor expression on human mononuclear cells. Immunopharmacology (2000) 48(2):117-28. doi:10.1016/S0162-3109(00)00195-8

100. Darcissac EC, Bahr GM, Parant MA, Chedid LA, Riveau GJ. Selective induction of CD11a,b,c/CD18 and CD54 expression at the cell surface of human leukocytes by muramyl peptides. Cell Immunol (1996) 169(2):294-301. doi:10.1006/cimm.1996.0121

101. Hsu YM, Zhang Y, You Y, Wang D, Li H, Duramad O, et al. The adaptor protein CARD9 is required for innate immune responses to intracellular pathogens. Nat Immunol (2007) 8(2):198-205. doi:10.1038/ni1426 
102. Sabbah A, Chang TH, Harnack R, Frohlich V, Tominaga K, Dube PH, et al. Activation of innate immune antiviral responses by NOD2. Nat Immunol (2009) 10(10):1073-80. doi:10.1038/ni.1782

103. Hugot JP, Chamaillard M, Zouali H, Lesage S, Cezard JP, Belaiche J, et al. Association of NOD2 leucine-rich repeat variants with susceptibility to Crohn's disease. Nature (2001) 411(6837):599-603. doi:10.1038/35079107

104. Ogura Y, Bonen DK, Inohara N, Nicolae DL, Chen FF, Ramos R, et al. A frameshift mutation in NOD2 associated with susceptibility to Crohn's disease. Nature (2001) 411(6837):603-6. doi:10.1038/35079114

105. Miceli-Richard C, Lesage S, Rybojad M, Prieur AM, Manouvrier-Hanu S, Hafner R, et al. CARD15 mutations in Blau syndrome. Nat Genet (2001) 29(1):19-20. doi:10.1038/ng720

106. Saiga H, Shimada $Y$, Takeda K. Innate immune effectors in mycobacterial infection. Clin Dev Immunol (2011) 2011:347594. doi:10.1155/2011/347594

107. Divangahi M, Mostowy S, Coulombe F, Kozak R, Guillot L, Veyrier F, et al. NOD2-deficient mice have impaired resistance to Mycobacterium tuberculosis infection through defective innate and adaptive immunity. J Immunol (2008) 181(10):7157-65. doi:10.4049/jimmunol.181.10.7157

108. Ferwerda G, Girardin SE, Kullberg BJ, Le Bourhis L, de Jong DJ, Langenberg DM, et al. NOD2 and toll-like receptors are nonredundant recognition systems of Mycobacterium tuberculosis. PLoS Pathog (2005) 1(3):279-85. doi:10.1371/journal.ppat.0010034

109. Khan N, Vidyarthi A, Pahari S, Negi S, Aqdas M, Nadeem S, et al. Signaling through NOD-2 and TLR-4 bolsters the T cell priming capability of dendritic cells by inducing autophagy. Sci Rep (2016) 6:19084. doi:10.1038/ srep19084

110. Kaufmann SH. How can immunology contribute to the control of tuberculosis? Nat Rev Immunol (2001) 1(1):20-30. doi:10.1038/35095558

111. Adorini L. Cytokine-based immunointervention in the treatment of autoimmune diseases. Clin Exp Immunol (2003) 132(2):185-92. doi:10.1046/j.1365-2249.2003.02144.x

112. Lee S, Margolin K. Cytokines in cancer immunotherapy. Cancers (Basel) (2011) 3(4):3856-93. doi:10.3390/cancers3043856

113. Thanendrarajan S, Nowak M, Abken H, Schmidt-Wolf IG. Combining cytokine-induced killer cells with vaccination in cancer immunotherapy: more than one plus one? Leuk Res (2011) 35(9):1136-42. doi:10.1016/j. leukres.2011.05.005

114. Pahari S, Khan N, Aqdas M, Negi S, Kaur J, Agrewala JN. Infergen stimulated macrophages restrict Mycobacterium tuberculosis growth by autophagy and release of nitric oxide. Sci Rep (2016) 6:39492. doi:10.1038/ srep39492

115. Singh V, Gowthaman U, Jain S, Parihar P, Banskar S, Gupta P, et al. Coadministration of interleukins 7 and 15 with bacille Calmette-Guerin mounts enduring $\mathrm{T}$ cell memory response against Mycobacterium tuberculosis. J Infect Dis (2010) 202(3):480-9. doi:10.1086/653827

116. Singh V, Jain S, Gowthaman U, Parihar P, Gupta P, Gupta UD, et al. Co-administration of IL-1+IL-6+TNF-alpha with Mycobacterium tuberculosis infected macrophages vaccine induces better protective $\mathrm{T}$ cell memory than BCG. PLoS One (2011) 6(1):e16097. doi:10.1371/journal.pone. 0016097

117. Gowthaman U, Rai PK, Khan N, Jackson DC, Agrewala JN. Lipidated promiscuous peptides vaccine for tuberculosis-endemic regions. Trends Mol Med (2012) 18(10):607-14. doi:10.1016/j.molmed.2012.07.008

118. Spisek R, Brazova J, Rozkova D, Zapletalova K, Sediva A, Bartunkova J. Maturation of dendritic cells by bacterial immunomodulators. Vaccine (2004) 22(21-22):2761-8. doi:10.1016/j.vaccine.2004.01.006

119. Khan N, Aqdas M, Vidyarthi A, Negi S, Pahari S, Agnihotri T, et al. Triggering through NOD-2 differentiates bone marrow precursors to dendritic cells with potent bactericidal activity. Sci Rep (2016) 6:27263. doi:10.1038/ srep27263

120. Persing DH, Coler RN, Lacy MJ, Johnson DA, Baldridge JR, Hershberg RM, et al. Taking toll: lipid A mimetics as adjuvants and immunomodulators. Trends Microbiol (2002) 10(10 Suppl):S32-7. doi:10.1016/S0966-842X(02) 02426-5

121. Bohannon JK, Hernandez A, Enkhbaatar P, Adams WL, Sherwood ER. The immunobiology of toll-like receptor 4 agonists: from endotoxin tolerance to immunoadjuvants. Shock (2013) 40(6):451-62. doi:10.1097/ SHK.0000000000000042
122. Wang H, Rayburn ER, Wang W, Kandimalla ER, Agrawal S, Zhang R. Immunomodulatory oligonucleotides as novel therapy for breast cancer: pharmacokinetics, in vitro and in vivo anticancer activity, and potentiation of antibody therapy. Mol Cancer Ther (2006) 5(8):2106-14. doi:10.1158/15357163.MCT-06-0158

123. Bessler WG. Synthetic lipopeptide immunomodulators derived from bacterial lipoprotein: tools for the standardization of in vitro assays. Dev Biol Stand (1992) 77:49-56.

124. Coffman RL, Sher A, Seder RA. Vaccine adjuvants: putting innate immunity to work. Immunity (2010) 33(4):492-503. doi:10.1016/j.immuni.2010. 10.002

125. Pabst O, Hornef M. Gut microbiota: a natural adjuvant for vaccination. Immunity (2014) 41(3):349-51. doi:10.1016/j.immuni.2014.09.002

126. Mohan T, Verma P, Rao DN. Novel adjuvants \& delivery vehicles for vaccines development: a road ahead. Indian J Med Res (2013) 138(5):779-95.

127. Sultana N, Saify ZS. Naturally occurring and synthetic agents as potential anti-inflammatory and immunomodulants. Antiinflamm Antiallergy Agents Med Chem (2012) 11(1):3-19. doi:10.2174/187152312803476264

128. Bhatia S, Dimde M, Haag R. Multivalent glycoconjugates as vaccines and potential drug candidates. Med Chem Commun (2014) 5(7):862-78. doi:10.1039/C4MD00143E

129. Bernardi A, Jimenez-Barbero J, Casnati A, De Castro C, Darbre T, Fieschi F, et al. Multivalent glycoconjugates as anti-pathogenic agents. Chem Soc Rev (2013) 42(11):4709-27. doi:10.1039/c2cs35408j

130. Montoya D, Inkeles MS, Liu PT, Realegeno S, Teles RM, Vaidya P, et al. IL-32 is a molecular marker of a host defense network in human tuberculosis. $\mathrm{Sci}$ Transl Med (2014) 6(250):250ra114. doi:10.1126/scitranslmed.3009546

131. Klug-Micu GM, Stenger S, Sommer A, Liu PT, Krutzik SR, Modlin RL, et al. CD40 ligand and interferon-gamma induce an antimicrobial response against Mycobacterium tuberculosis in human monocytes. Immunology (2013) 139(1):121-8. doi:10.1111/imm.12062

132. Daley P, Jagannathan V, John KR, Sarojini J, Latha A, Vieth R, et al. Adjunctive vitamin D for treatment of active tuberculosis in India: a randomised, double-blind, placebo-controlled trial. Lancet Infect Dis (2015) 15(5):528-34. doi:10.1016/S1473-3099(15)70053-8

133. Tukvadze N, Sanikidze E, Kipiani M, Hebbar G, Easley KA, Shenvi N, et al. High-dose vitamin D3 in adults with pulmonary tuberculosis: a double-blind randomized controlled trial. Am JClin Nutr (2015) 102(5):1059-69. doi:10.3945/ajcn.115.113886

134. Jurado JO, Alvarez IB, Pasquinelli V, Martinez GJ, Quiroga MF, Abbate E, et al. Programmed death (PD)-1:PD-ligand 1/PD-ligand 2 pathway inhibits $\mathrm{T}$ cell effector functions during human tuberculosis. J Immunol (2008) 181(1):116-25. doi:10.4049/jimmunol.181.1.116

135. Singh A, Mohan A, Dey AB, Mitra DK. Inhibiting the programmed death 1 pathway rescues Mycobacterium tuberculosis-specific interferon gammaproducing $\mathrm{T}$ cells from apoptosis in patients with pulmonary tuberculosis. J Infect Dis (2013) 208(4):603-15. doi:10.1093/infdis/jit206

136. Li N, Xie WP, Kong H, Min R, Hu CM, Zhou XB, et al. Enrichment of regulatory T-cells in blood of patients with multidrug-resistant tuberculosis. Int J Tuberc Lung Dis (2015) 19(10):1230-8. doi:10.5588/ijtld.15.0148

137. Singh A, Dey AB, Mohan A, Sharma PK, Mitra DK. Foxp3+ regulatory $T$ cells among tuberculosis patients: impact on prognosis and restoration of antigen specific IFN-gamma producing T cells. PLoS One (2012) 7(9):e44728. doi:10.1371/journal.pone.0044728

138. McNab FW, Berry MP, Graham CM, Bloch SA, Oni T, Wilkinson KA, et al. Programmed death ligand 1 is over-expressed by neutrophils in the blood of patients with active tuberculosis. Eur J Immunol (2011) 41(7):1941-7. doi:10.1002/eji.201141421

139. Singh A, Dey AB, Mohan A, Mitra DK. Programmed death-1 receptor suppresses gamma-IFN producing NKT cells in human tuberculosis. Tuberculosis (Edinb) (2014) 94(3):197-206. doi:10.1016/j.tube.2014.01.005

140. Garcia Jacobo RE, Serrano CJ, Enciso Moreno JA, Gaspar Ramirez O, Trujillo Ochoa JL, Uresti Rivera EE, et al. Analysis of Th1, Th17 and regulatory T cells in tuberculosis case contacts. Cell Immunol (2014) 289(1-2):167-73. doi:10.1016/j.cellimm.2014.03.010

141. Merlo A, Saverino D, Tenca C, Grossi CE, Bruno S, Ciccone E. CD85/ LIR-1/ILT2 and CD152 (cytotoxic T lymphocyte antigen 4) inhibitory molecules down-regulate the cytolytic activity of human CD4+ T-cell clones 
specific for Mycobacterium tuberculosis. Infect Immun (2001) 69(10):6022-9. doi:10.1128/IAI.69.10.6022-6029.2001

142. Sierro S, Romero P, Speiser DE. The CD4-like molecule LAG-3, biology and therapeutic applications. Expert Opin Ther Targets (2011) 15(1):91-101. doi: 10.1517/14712598.2011.540563

143. Phillips BL, Mehra S, Ahsan MH, Selman M, Khader SA, Kaushal D. LAG3 expression in active Mycobacterium tuberculosis infections. Am J Pathol (2015) 185(3):820-33. doi:10.1016/j.ajpath.2014.11.003

144. Ngiow SF, Teng MW, Smyth MJ. Prospects for TIM3-targeted antitumor immunotherapy. Cancer Res (2011) 71(21):6567-71. doi:10.1158/0008-5472. CAN-11-1487

145. Sada-OvalleI,Chavez-GalanL, Torre-BouscouletL,Nava-GaminoL,BarreraL, Jayaraman $\mathrm{P}$, et al. The Tim3-galectin 9 pathway induces antibacterial activity in human macrophages infected with Mycobacterium tuberculosis. J Immunol (2012) 189(12):5896-902. doi:10.4049/jimmunol.1200990

146. Sada-Ovalle I, Ocana-Guzman R, Perez-Patrigeon S, Chavez-Galan L, SierraMadero J, Torre-Bouscoulet L, et al. Tim-3 blocking rescue macrophage and $\mathrm{T}$ cell function against Mycobacterium tuberculosis infection in HIV+ patients. J Int AIDS Soc (2015) 18:20078. doi:10.7448/IAS.18.1.20078

147. Hancock RE, Sahl HG. Antimicrobial and host-defense peptides as new anti-infective therapeutic strategies. Nat Biotechnol (2006) 24(12):1551-7. doi: $10.1038 /$ nbt1267

148. Hamill P, Brown K, Jenssen H, Hancock RE. Novel anti-infectives: is host defence the answer? Curr Opin Biotechnol (2008) 19(6):628-36. doi:10.1016/j. copbio.2008.10.006

149. Mahima AM, Ingle AM, Verma AK, Tiwari R, Karthik K, Chakraborty S, et al. Immunomodulators in day to day life: a review. Pak J Biol Sci (2013) 16(17):826-43. doi:10.3923/pjbs.2013.826.843

150. Szumowski JD, Adams KN, Edelstein PH, Ramakrishnan L. Antimicrobial efflux pumps and Mycobacterium tuberculosis drug tolerance: evolutionary considerations. Curr Top Microbiol Immunol (2013) 374:81-108. doi:10.1007/82_2012_300

151. Ughachukwu P, Unekwe P. Efflux pump-mediated resistance in chemotherapy. Ann Med Health Sci Res (2012) 2(2):191-8. doi:10.4103/2141-9248.105671

152. Almeida Da Silva PE, Palomino JC. Molecular basis and mechanisms of drug resistance in Mycobacterium tuberculosis: classical and new drugs. J Antimicrob Chemother (2011) 66(7):1417-30. doi:10.1093/jac/dkr173

153. Nachega JB, Chaisson RE. Tuberculosis drug resistance: a global threat. Clin Infect Dis (2003) 36(Suppl 1):S24-30. doi:10.1086/344657

154. Shehzad A, Rehman G, Ul-Islam M, Khattak WA, Lee YS. Challenges in the development of drugs for the treatment of tuberculosis. Braz J Infect Dis (2013) 17(1):74-81. doi:10.1016/j.bjid.2012.10.009

155. van den Boogaard J, Kibiki GS, Kisanga ER, Boeree MJ, Aarnoutse RE. New drugs against tuberculosis: problems, progress, and evaluation of agents in clinical development. Antimicrob Agents Chemother (2009) 53(3):849-62. doi:10.1128/AAC.00749-08

156. Berkner S, Konradi S, Schonfeld J. Antibiotic resistance and the environment - there and back again: science \& society series on science and drugs. EMBO Rep (2014) 15(7):740-4. doi:10.15252/embr.201438978
157. Rayasam GV, Balganesh TS. Exploring the potential of adjunct therapy in tuberculosis. Trends Pharmacol Sci (2015) 36(8):506-13. doi:10.1016/j. tips.2015.05.005

158. Hennessy EJ, Parker AE, O’Neill LA. Targeting toll-like receptors: emerging therapeutics? Nat Rev Drug Discov (2010) 9(4):293-307. doi:10.1038/nrd3203

159. Blach-Olszewska Z, Leszek J. Mechanisms of over-activated innate immune system regulation in autoimmune and neurodegenerative disorders. Neuropsychiatr Dis Treat (2007) 3(3):365-72.

160. Vanderlugt CL, Miller SD. Epitope spreading in immune-mediated diseases: implications for immunotherapy. Nat Rev Immunol (2002) 2(2):85-95. doi:10.1038/nri724

161. Rice TW, Wheeler AP, Bernard GR, Vincent JL, Angus DC, Aikawa N, et al. A randomized, double-blind, placebo-controlled trial of TAK-242 for the treatment of severe sepsis. Crit Care Med (2010) 38(8):1685-94. doi:10.1097/ CCM.0b013e3181e7c5c9

162. Antonelli LR, Gigliotti Rothfuchs A, Goncalves R, Roffe E, Cheever AW, Bafica A, et al. Intranasal poly-IC treatment exacerbates tuberculosis in mice through the pulmonary recruitment of a pathogen-permissive monocyte/ macrophage population. J Clin Invest (2010) 120(5):1674-82. doi:10.1172/ JCI40817

163. Tidswell M, Tillis W, Larosa SP, Lynn M, Wittek AE, Kao R, et al. Phase 2 trial of eritoran tetrasodium (E5564), a toll-like receptor 4 antagonist, in patients with severe sepsis. Crit Care Med (2010) 38(1):72-83. doi:10.1097/ CCM.0b013e3181b07b78

164. Barochia A, Solomon S, Cui X, Natanson C, Eichacker PQ. Eritoran tetrasodium (E5564) treatment for sepsis: review of preclinical and clinical studies. Expert Opin Drug Metab Toxicol (2011) 7(4):479-94. doi:10.1517/17425255. 2011.558190

165. Zumla A, Rao M, Parida SK, Keshavjee S, Cassell G, Wallis R, et al. Inflammation and tuberculosis: host-directed therapies. J Intern Med (2015) 277(4):373-87. doi:10.1111/joim.12256

166. Karin M, Lawrence T, Nizet V. Innate immunity gone awry: linking microbial infections to chronic inflammation and cancer. Cell (2006) 124(4):823-35. doi:10.1016/j.cell.2006.02.016

167. Gowthaman U, Mushtaq K, Tan AC, Rai PK, Jackson DC, Agrewala JN. Challenges and solutions for a rational vaccine design for TB-endemic regions. Crit Rev Microbiol (2015) 41(3):389-98. doi:10.3109/1040841X.2013.859125

Conflict of Interest Statement: The authors declare that the research was conducted in the absence of any commercial or financial relationships that could be construed as a potential conflict of interest.

Copyright $\odot 2017$ Pahari, Kaur, Aqdas, Negi, Chatterjee, Bashir, Singh and Agrewala. This is an open-access article distributed under the terms of the Creative Commons Attribution License (CC BY). The use, distribution or reproduction in other forums is permitted, provided the original author(s) or licensor are credited and that the original publication in this journal is cited, in accordance with accepted academic practice. No use, distribution or reproduction is permitted which does not comply with these terms. 